\title{
Investigation of Red Cell Antiobody Screening Tests Gyeonggi Areas
}

\author{
Dai-Joong Kim ${ }^{1}$, Hyun-Ho Sung ${ }^{2}$, and Chang-Eun Park ${ }^{3}$ \\ ${ }^{1}$ Department of Laboratory Medicine, Bundang Jesaeng Hospital, Seongnam 13590, Korea \\ ${ }^{2}$ Department of Clinical Laboratory Science, Dongnam Health University, Suwon 16328, Korea \\ ${ }^{3}$ Department of Biomedical Laboratory Science, Molecular Diagnostics Research Institute, Namseoul University, Cheonan 31020, Korea
}

\section{경기일부지역의 적혈구 항체선별검사의 실태조사}

\author{
김대중 ${ }^{1}$, 성현호 $^{2}$, 박창은 $^{3}$ \\ ${ }^{1}$ 분당제생병원 진단검사의학과, ${ }^{2}$ 동남보건대학교 임상병리과, ${ }^{3}$ 남서울대학교 임상병리학과 분자진단연구소
}

\begin{abstract}
Red blood cell (RBC) alloimmunization results from genetic disparity of RBC antigens between donor and recipients. The discrepancy of RBC antibody screening test occurs when the results of red cell tests do not agree with those of the serum test. In order to select the proper blood units for transfusion, clarification of the cause of discrepancies is essential. The RBC antibody screening test is an easy, quick, and reliable method for detection of clinically significant antibodies. Antibody screening and identification is recommended prior to transfusion to determine whether there is blood group incompatibility. We reported that phenotyping for E, D, M, E+c, and C+e antibody screening test should be extended. Therefore, these results indicate that anti-D and anti-E alloantibodies were major risk factors for haemolytic disease of the newborn or delayed haemolytic transfusion reactions in this study population. We suggested that its antibody screening be adapted to blood safety interventions. Targeted screening of selected recipients at risk offers less value than universal antibody screening, and more research is needed to determine the real incidence of this national condition.
\end{abstract}

Keywords: Alloimmunization, Red blood cell antibody screening test, Transfusion

This is an Open Access article distributed under the terms of the Creative Commons Attribution Non-Commercial License (http://creativecommons.org/licenses/by-nc/4.0) which permits unrestricted non-commercial use, distribution, and reproduction in any medium, provided the original work is properly cited.

Copyright (@) 2016 The Korean Society for Clinical Laboratory Science. All rights reserved.
Corresponding author: Chang-Eun Park Department of Biomedical Laboratory Science, Molecular Diagnostics Research Institute, Namseoul University, 91 Daehak-ro,

Seonghwan-eup, Seobuk-gu, Cheonan 31020 , Korea

Tel: 82-41-580-2722

Fax: 82-41-580-2932

E-mail: eun2777@hanmail.net

Received: January 18, 2016 Revised $1^{\text {st. }}$ February 1, 2016

Revised 2 ${ }^{\text {nd: }}$ : February 1, 2016

Revised $3^{\text {rd: }}$ February 2, 2016

Revised $4^{\text {th }}$ : February 3, 2016

Accepted: February 3, 2016

\section{Introduction}

Red blood cell with alloimmunization, hetero- immunization and autoimmunization is generally a complication among transfusion recipients [1]. Unexpected antibodies can cause acute or delayed hemolytic transfusion reactions. Patients with pregnancy history showed a significantly higher frequency of unexpected antibodies than those without pregnancy history. Evaluated amounts and frequency of antigen exposure to transfusion and pregnancy is suggested to increase the frequency of identification of unexpected antibody.

The alloimmunization occurs when incompatible antigens introduced in an immune-competent host evoke an immune response leading to irregular antibody formation. Alloimmunization against RBCs can result in delayed hemolytic 
transfusion reactions. Considering both patient safety and cost effectiveness, we recommend the use of a conditional combination of LISS/Coombs and $\mathrm{NaCl}$ /Enzyme gels for antibody detection, especially in laboratories that must perform tests within an established budget [1]. Also, performed by column agglutination method [2].

The gel test is a commonly used column agglutination technique and polyethylene glycol antiglobulin test [3] for unexpected antibody detection. About 25 28 antigens are known to cause hemolytic transfusion reactions and should be detected with the pretransfusion RBC antibody screening test [4]. The Rhesus (Rh), Kell (K), Duffy (Fy), and Kidd (Jk) antigens are some of these clinically significant blood group antigens. The rate of $\mathrm{RBC}$ alloimmunization has been reported in the range of $5 \sim 30 \%$ among the multiply transfused patients [5].

The antibody screening and crossmatching was done by an indirect antiglobulin test, performed by gel agglutination technique using Diamed gel cards. For antibody screening, 3-cell screening panels (Diamed ID-Dia cell) were used. The positive results were then further identified for antibody specificity by the Diamed ID-Dia Panel (11 cell panel), including the use of enzyme treated cells (papain) at $37^{\circ} \mathrm{C}$ and anti human globulin phase.

The RBC antibody screening was carried out in a fully automated process with a 3-cell panel (0.8\% Surgiscreen RBCs reagents 1, 2, and 3 [Ortho-Clinical Diagnostics Inc., Raritan, NJ, USA]) in the LISS-indirect antiglobulin test (IAT). Additionally an enzyme test with 3 enzyme-pretreated (papain) red test cells (ID-DiaCell PI, PII, PIII [BIO-RAD, Hercules, CA, USA]) was performed on the ORTHO AutoVue ${ }^{\circledR}$ Innova System (Ortho-Clinical Diagnostics Inc., Raritan, NJ, USA).

For identification, the RBC antibody screening showed a positive result in the LISS-IAT and/or with the enzyme-test (papain). The antibody identification was carried out manually with an 11-cell panel (ID-DiaPanel 1 11 [BIO-RAD, Hercules, CA]) in the LISS-IAT and with an enzyme-pretreated (papain) 11-cell panel (ID-DiaPanel-P 1 11 [BIO-RAD, Hercules, CA]). If a specific RBC alloantibody was identified, the corresponding blood group antigen was determined to confirm the RBC antibody identification result. The autocontrol was made in the LISS-IAT. Serological reactions were graded from 0 to $4^{+}[6]$.

We performed data statistics analysis to analyze the serological $\mathrm{ABO}$ and $\mathrm{Rh}$ phenotype frequencies and the frequencies and specificities of the RBC alloantibodies. The automated instrument (AutoVue Innova [Ortho-Clinical Diagnostics Inc., Raritan, NJ, USA]) had high levels of accuracy and performance, It is expected that use of a fully automated instrument will reduce human labor, turn around time, and operator error in the blood bank.

As an alternative to the time consuming process of alloantibody detection, patients with severe anemia can be effectively transfused with "least incompatible units" in an emergency clinical setting, without experiencing acute transfusion reactions. The $\mathrm{NaCl} /$ Enzyme combined with the LISS/Coombs gel test was very useful for the identification of unexpected antibodies.

In Korea, multiple ethnicity of the population has caused genetic heterogeneity among the population with a wide variation of antibody specificity. The objective of this study was to analyze the frequency and specificity of the red cell antibody detected during the pre-transfusion testing among the transfusion recipients of some in the Gyeonggi province area, and to evaluate the time interval between the transfusion and detection of alloantibodies.

\section{Materials and Methods}

Unexpected antibody tests performed in a Gyeonggi ares hospital during recent 1 yr (January 2013 December 2013) were retrospectively analyzed: antibody screening was performed for 35,841 samples; subsequently, antibodies were identified in samples showing positive screening results. Antibodies had been screened and identified using LISS/Coombs gel cards with DiaMed-ID system (DiaMed AG, Cressier sur Morat, Switzerland). All initial screening and identification tests were carried out using the LISS/Coombs gel assay (DiaMed AG, Cressier sur Morat, Switzerland). Briefly, a $50-\mu \mathrm{L}$ sample of $0.8 \%$ screening or identification cell reagent (DiaMed AG) was added to the microtube of each gel 
card along with $25 \mu \mathrm{L}$ of patient serum. After $15 \mathrm{~min}$ of incubation at $37^{\circ} \mathrm{C}$, the card was centrifuged for $10 \mathrm{~min}$ at 910 rpm, and the agglutination reactions were examined macroscopically. An autocontrol was performed simultaneously by conducting a reaction between the patient's serum and $0.8 \%$ red blood cells, instead of reagent cells, from the same patient. An antibody was "identified" if all reactions in the 11 wells were consistent with the manufacturer's identification table and "negative" if no agglutination reaction occurred in any of the 11 wells. An antibody screening result was considered positive if one or both of the reagent cells agglutinated with the patient's serum in the LISS/Coombs gel test. For the LISS/Coombs identification test, the LISS/Coombs card and ID-Panel test reagent (DiaMed Ag) were used. For the $\mathrm{NaCl} /$ Enzyme identification test, the $\mathrm{NaCl} /$ Enzyme card and the ID-Panel P test reagent (DiaMed Ag) were used.

Table 1. Comparison of the distributed incidence of identified antibodies in partially Korea and Malaysia

\begin{tabular}{|c|c|c|}
\hline Class of antibody & $\begin{array}{c}\text { Korea } \\
\text { (2013 years) } \\
\text { N (\%) }\end{array}$ & $\begin{array}{c}\text { Malaysia } \\
\text { (2010 years) } \\
\text { N (\%)* }\end{array}$ \\
\hline Anti-C+e & $5(5.5)$ & $1(0.8)$ \\
\hline Anti-C+e+N (autoantibody) & $2(2.2)$ & - \\
\hline Anti-C+N (alloantibody) & $1(1.1)$ & - \\
\hline Anti-D & $4(4.4)$ & $21(16.0)$ \\
\hline Anti-D+E & $1(1.1)$ & - \\
\hline Anti-E & $37(40.6)$ & $19(14.5)$ \\
\hline Anti-E+Fy ${ }^{a}$ & $1(1.1)$ & - \\
\hline Anti-E+C & $16(17.6)$ & $7(5.3)$ \\
\hline Anti-E+Le $\mathrm{a}^{\mathrm{a}}$ & $1(1.1)$ & - \\
\hline Anti-Fy & $3(3.3)$ & $1(0.8)$ \\
\hline Anti-Jk $\mathrm{k}^{\mathrm{a}}$ & $1(1.1)$ & $7(5.3)$ \\
\hline Anti-Jk $k^{b}$ & $1(1.1)$ & $1(0.8)$ \\
\hline Anti-Le ${ }^{a}$ & $2(2.2)$ & $2(1.5)$ \\
\hline Anti-Le $e^{a}+L e^{b}$ & $1(1.1)$ & $2(1.5)$ \\
\hline Anti-M & $11(12.1)$ & $3(2.4)$ \\
\hline Anti-Mia & - & $48(36.6)$ \\
\hline Anti-MUT & - & $7(5.3)$ \\
\hline Anti-N & $1(1.1)$ & $2(1.5)$ \\
\hline Anti-P1 & $3(3.3)$ & $6(4.6)$ \\
\hline Anti-S & - & $4(3.1)$ \\
\hline Total & $2,104(100)$ & $2,137(100)$ \\
\hline
\end{tabular}

*Analysed all the red cell antibodies and calculated the incidence of clinically significant red cell alloantibodies in Malaysia Medical Center (UKMMC) of the pre-transfusion testing results performed from 2010 years [7].

\section{Results}

The frequencies and specificities of RBC alloantibodies detected in the LISS-IAT and enzyme (papain) are illustrated in Table 1. Table 1 describes the specificity of the unexpected antibody and detected RBC alloantibodies among Korea (2013) and Malaysia (2010 years).

\section{Discussion}

In Korea, alloantibodies have been reported in $0.3 \%$ $1.73 \%$ of patient samples depending on the study group, sensitivity, and test methods used [8]. In this study, a single alloantibody was found most frequently. In Malaysia, the Anti-Mia was observed with the greatest frequency among these alloantibodies. In Korea, the Anti-E has been detected with frequent antibodies. The first reported anti-Mia study in Taiwan also showed a similar result whereby anti-Mia was the most frequently occurring alloantibody [9].

Alloimmunization can cause a hemolytic transfusion reaction in individuals lacking the corresponding blood group antigen on their erythrocytes [10].

Anti-E, anti-D and anti-M were the most common alloantibodies in this study population. The heterogeneity of the populations involved, the different screening protocols, variations in the definition of clinically significant antibodies and different antibody identification techniques might account for the above differences. However, a history of transfusion and/or pregnancy was significantly correlated with alloantibody formation [11].

Among Americans, the most frequently identified alloantibodies were anti-E (20.8\%), anti-Lea (18.6\%), anti-K (14.7\%) and anti-D (12.9\%) [12].

If the $\mathrm{E}$ antigen in the Rhesus blood group is detected as often as the $\mathrm{D}$ antigen in transfusion practice, high-risk groups, such as those with the anti-E antibody and those undergoing chronic transfusion therapy or transplantation, will benefit.

Erythrocyte alloimunization anti-D antibodies decrease in connection with the introduction of immunoprofylaxis. Immunization of non Rh D antibodies with the impossibility 


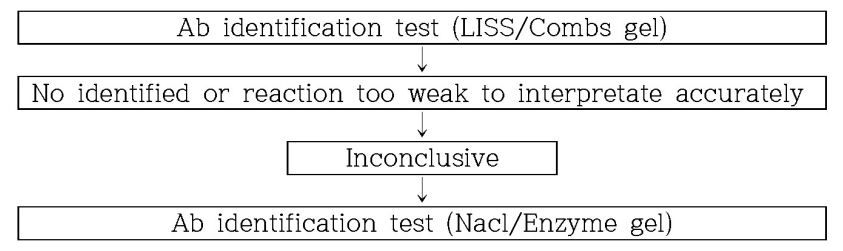

Fig. 1. Test flow chart according to the results of antibody screening and identification tests [1]. Ab; RBC irregular antibody.

of using immunoprofylaxis still remains a clinical problem [13].

Alloimmunization increases the time required for crossmatching and may delay treatment, in addition to increasing the chances of transfusion reactions. To avoid the effects of alloimmunization, routine RBC antibody screening at set time intervals after transfusion i.e. repeat antibody screens of the patient if the time interval between two transfusions is more than 72 hours, should be ensured [14].

Fayek et al. [15] suggest flow cytometry is more sensitive than gel tests for assessing conventional tube technique direct antiglobulin test-negative autoimmune haemolytic anemia

Shin [1] reported that results were "inconclusive" when a specific antibody was not identified, or the test reactions were too weak to interpret accurately. $\mathrm{NaCl} /$ Enzyme gel (DiaMed AG) was added for additional antibody identification if the results of the LISS/Coombs gel test were inconclusive (Fig. 1).

Recent study in Taiwan [16] and East Asian populations [17] were showed similar to Anti-Mia frequently occurring alloantibody. But, In Caucasians, this phenotype is very rare incidence of $0.01 \%$ [18]. Thus, pretransfusion antibody screening on patients' sample prior to crossmatching needs to be initiated in Asian to ensure safe transfusion practice.

To accurately identify unexpected antibodies the use of a combination of the LISS/Coombs and NaCl/Enzyme gel tests is recommended. However, many laboratories in Korea perform antibody screening and identification tests using only the LISS/Coombs gel test because the coverage of related medical fees is too low.

We showed that the overall prevalence of alloantibodies was $57.1 \%$, with anti-E, anti-D and anti-M being the most frequently identified alloantibodies in the hospitalized. Further studies should be performed to collect sufficient evidence for anti-D prophylaxis in obstetric practice.

\section{요 약}

적혈구 동종면역은 수혈자와 공여자간의 적혈구 항원의 차이이 다. 수혈을 위해서는 혈구형과 혈청형이 일치하지 않으면 적혈구 항체 선별 검사가 필요하며 불일치의 원인을 해명하는 것이 필수적 이다. 적혈구 항체 선별검사는 임상적으로 유의한 항체를 검출하 고, 신속 정확하며, 신뢰할 수 있는 방법으로 수혈에 앞서 우선적으 로 하는 것을 권장한다. 본 연구자들은 다빈도로 검출된 $\mathrm{E}, \mathrm{D}, \mathrm{M}$, $\mathrm{E}+\mathrm{c}, \mathrm{C}+\mathrm{e}$ 항체에 대한 선별검사를 보고하였다. 따라서 이러한 결 과로 항-D, 항-E의 항체가 신생아 용혈성 질환, 지연형 용혈성 수 혈부작용 반응의 위험요인으로 인식하고자 한다. 또한 혈액안전관 리를 적용하기 위해 적합한 항체선별검사가 요구되고, 수혈 위험요 인의 선별에 있어 더 나은 효율성을 제공할 것이며 향후에 각 국가 에 따라 실질적인 검출빈도를 찾는 연구가 필요할 것으로 사료된다.

\section{Acknowledgements: None}

Funding: None

Conflict of interest: None

\section{References}

1. Shin JW. Unexpected red cell antibody detection by conditional combination of LISS/Coombs and $\mathrm{NaCl}$ /Enzyme gel tests at a tertiary care hospital in Korea: A 5-year study. Blood Res. 2013;48:217-221.

2. Lee GH, Gye HI, You SY, Chung CH, Cho MJ, Kim DE. Factors influencing the sensitivity of antibody screening tests with microplate and column agglutination method. Korean J Clin Lab Sci. 1998;30:193-198.

3. Lee JS, Kim DE, Kim DK. Evaluation of the polyethylene glycol antiglobulin test for routine antibody screening test. Korean J Clin Lab Sci. 1998;30:214-221.

4. Pathak S, Chandrashekhar M, Whankhede GR. Type and screen policy in the blood bank: is AHG cross-match still required? a study at a multispeciality corporate hospital in India. Asian J Transfus Sci. 2011;5:153-156.

5. Natukunda B, Schonewille H, van de Watering L, Brand A. Prevalence and specificities of red blood cell alloantibodies in transfused Ugandans with different diseases. Vox Sang. 2010;98:167-171.

6. Enko D, Habres C, Wallner F, Mayr B, Halwachs-Baumann G. Frequencies and specificities of "enzyme-only" detected erythrocyte alloantibodies in patients hospitalized in austria: is an enzyme test required for routine red blood cell antibody screening?. J Blood Transfus. 2014;2014:532919.

7. Yousuf R, Abdul Aziz S, Yusof N, Leong CF. Incidence of red cell 
alloantibody among the transfusion recipients of universiti Kebangsaan Malaysia medical centre. Indian J Hematol Blood Transfus. 2013;29:65-70.

8. Song DH, Moon IS, Hong SJ, Park JH, Kim JG, Jeon DS. Frequency and distribution of unexpected antibodies of Koreans. Korean J Blood Transfus. 1998;9:191-200.

9. Broadberry RE, Lin M. The incidence and significance of anti-"Mia" in Taiwan. Transfusion. 1994;34:349-352.

10. Branch DR. Solving the dilemma of prevention of red cell alloimmunization. Immunotherapy. 2012;4:903-905.

11. Xu P, Li Y, Yu H. Prevalence, specificity and risk of red blood cell alloantibodies among hospitalised Hubei Han Chinese patients. Blood Transfus. 2014;12:56-60.

12. Winters JL, Pineda AA, Gorden LD, Bryant SC, Melton LJ 3rd, Vamvakas EC, et al. RBC alloantibody specificity and antigen potency in Olmsted County, Minnesota. Transfusion. 2001; 41:1413-1420.

13. Holusková I, Lubušký M, Studničková M, Procházka M. Erythrocyte alloimmunization in pregnant women, clinical im- portance and laboratory diagnostics. Ceska Gynekol. 2013; 78:89-99.

14. Sood R, Makroo RN, Riana V, Rosamma NL. Detection of alloimmunization to ensure safer transfusion practice. Asian J Transfus Sci. 2013;7:135-139.

15. Fayek MH, Saad AA, Eissa DG, Tawfik LM, Kamal G. Role of gel test and flow cytometry in diagnosis of Coombs' negative autoimmune haemolytic anaemia. Int J Lab Hematol. 2012;34: 311-319.

16. Jan RH, Yu LC, Wen SH, Tsai SS, Lin TY. Incidence of alloantibodies in transfused patients in Eastern Taiwan. Tzu Chi Med J. 2009;21:66-69.

17. Heathcote DJ, Carroll T, Wang JJ, Flower R, Rodionov I, Tuzikov A, et al. Novel antibody screening cells, MUT+Mur kodecytes, created by attaching peptides onto red blood cells. Transfusion. 2010;50:635-641.

18. Wu KH, Chang JG, Lin M, Shih MC, Lin HC, Lee C, et al. Hydrops foetalis caused by anti-Mur in first pregnancy-a case report. Transfus Med. 2002;12:325-327. 